\title{
Application of dry-state adsorption condition (DSAC) Pauson- Khand cyclization for the synthesis of perhydrocyclopenta[c]pyrroles
}

\author{
Marko D. Mihovilovic*, Christian Adelwöhrer, and Peter Stanetty \\ Institute of Organic Chemistry, Vienna University of Technology, Getreidemarkt 9/154, A-1060 \\ Vienna, Austria \\ E-mail: mmihovil@pop.tuwien.ac.at
}

Dedicated to Prof. Fritz Sauter on the occasion of his $70^{\text {th }}$ birthday

(received 15 Nov 00; accepted 28 Oct 01; published on the web 05 Nov 01)

\begin{abstract}
A simplified protocol of dry-state adsorption condition (DSAC) Pauson-Khand cyclizations for the preparation of the title compounds and the synthesis of a variety of perhydrocyclopenta[ $c]$ pyrrolones, are reported. In one case the formation of a monocyclic compound was observed in varying amounts depending on the reaction atmosphere.
\end{abstract}

Keywords: Pauson-Khand cyclization, dry state adsorption conditions, solid phase; perhydrocyclopenta[c]pyrroles, dicobalt octacarbonyl

\section{Introduction}

The Pauson-Khand reaction represents one of the most important methods for the formation of five-membered ring systems. In a formal $[2+2+1]$ cycloaddition a transition metal - in most cases $\mathrm{Co}_{2}(\mathrm{CO})_{8}$ - forms a complex with an alkyne which subsequently reacts with an alkene component with concomitant CO insertion (Scheme 1). The final reductive elimination of the metal results in an enone moiety. Though direct mechanistic evidence is lacking beyond the alkyne-complexation a hypothesis has been inferred from observations of the regio- and stereochemistry in a large number of examples. ${ }^{1}$

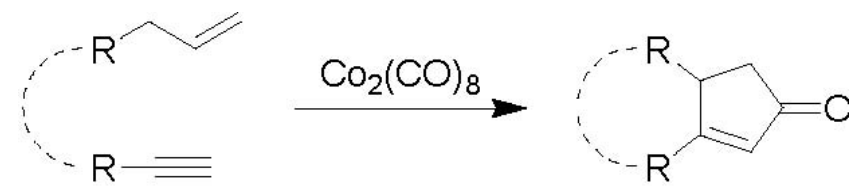

Scheme 1 
From the synthetic point of view it is relevant that generally the intramolecular version of the Pauson-Khand cyclization gives better results than the intermolecular. However, in the case of an intramolecular reaction it is necessary to use equimolar amounts of the metal carbonyl while for an intermolecular cyclization catalytic quantities are sufficient.

In the course of our investigations in the field of whole-cell mediated Baeyer-Villiger oxidation $^{2}$ we became interested in bicyclic structures of type 3 (Scheme 2).

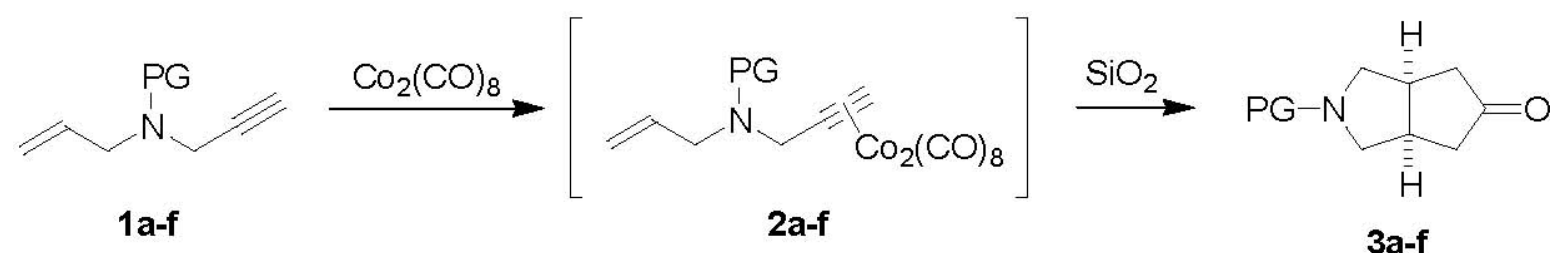

\begin{tabular}{c|ll}
$\mathbf{1 , 2 , 3}$ & $\mathrm{PG}$ & $\mathbf{3}(\%)$ \\
\cline { 2 - 3 } $\mathbf{a}$ & $\mathrm{Ac}$ & 60 \\
$\mathbf{b}$ & $\mathrm{F}_{3} \mathrm{CCO}$ & 42 \\
$\mathbf{c}$ & $\mathrm{PhCO}$ & 76 \\
$\mathbf{d}$ & $\mathrm{MeO}_{2} \mathrm{C}$ & 61 \\
e & $\mathrm{Boc}_{1}$ & 56 \\
$\mathbf{f}$ & $\mathrm{Tos}$ & 52
\end{tabular}

\section{Scheme 2}

An interesting approach to this class of compounds was initially reported by Pauson et al. ${ }^{3}$ and later by Becker and coworkers ${ }^{4}$ applying dry-state adsorption conditions (DSAC). In the case of $N$-protected nitrogen precursors DSAC Pauson-Khand cyclization gives predominately saturated bicyclic products. This modified DSAC protocol for the cobalt catalyzed reaction was first investigated in detailed studies by Smit et al. ${ }^{5}$ and the outcome of the cyclization is highly dependent on the reaction atmosphere applied. DSAC offers in some cases the advantage to decrease reaction times and/or induction temperatures compared to standard thermal PausonKhand reactions. ${ }^{6}$

\section{Results and Discussion}

In order to simplify the protocol for DSAC Pauson-Khand transformation we optimized the route to a number of novel as well as known cyclopenta[c]pyrrol-5-ones 3a-f. The starting materials for the cyclization were prepared according to standard literature procedures ${ }^{3}$ utilizing $N$-allyl- $N$ (2-propynyl)amine ${ }^{7}$ and the corresponding acid halide or anhydride.

The metal complex 2a-f was formed in ethereal solution with evolution of CO. In contrast to earlier reports we did not find it necessary to isolate the cobalt complex via chromatography but 
rather used the crude material for the cyclization. This reduces the handling of highly toxic cobalt compounds to a minimum, thus improving laboratory safety significantly, and in addition, the time efficiency of the process is increased. We used the ethereal solution of the complex formation directly and adsorbed it onto the surface of a solid phase (silica gel). Sufficient homogeneous distribution of the complex 2a-f on the solid phase was achieved by rotation of a baffled flask with the suspension on a rotary evaporator while stripping off the solvent.

Subsequently, raising the water bath temperature to $70{ }^{\circ} \mathrm{C}$ induced the cyclization. A change of color from rusty-red to deep blue can be used to monitor the reaction progress.

The isolated yields of products 3a-f (Scheme 2) obtained via this simplified one-pot procedure are in the range of $42-76 \%$ and slightly exceeding or at least comparable to those reported in the literature (41-66\% overall for two steps). ${ }^{3,4}$ In this procedure the cobalt-complex intermediate was not purified prior to the cyclization posing no problem for the isolation of products 3a-f. When the reaction was carried out in a nitrogen atmosphere exclusive formation of the perhydro compounds 3 was observed consistent with previous results. ${ }^{3,4}$ Efficient work-up of the solid phase reaction included elution of the crude material followed by chromatographic purification. Dilute conditions have to be maintained to ensure optimized conversion and yield for the cyclization step. Best results were obtained with approximately $10 \mathrm{~g}$ of commercially available silica gel per mmol of substrate.

In the case of trifluoroacetamide 1b strict exclusion of oxygen was crucial for a successful cyclization. Otherwise the monocyclic ketone $\mathbf{4}$ was obtained as a by-product. The amount of 4 isolated increased with higher concentrations of oxygen.

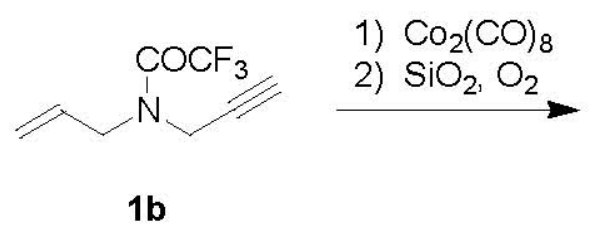

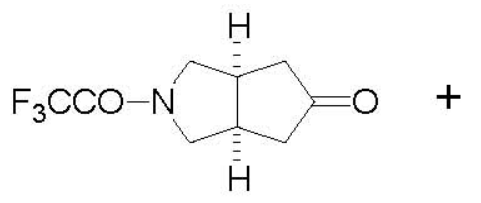

$3 \mathbf{b}$

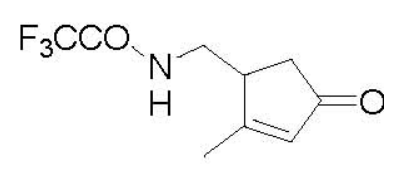

4

\section{Scheme 3}

Such an influence of the hetero atom on the reaction pathway of nitrogen precursors in a DSAC Pauson-Khand cyclization has not been reported before. However, Smit and coworkers observed a reversed behavior of the precursors to the corresponding cyclopenta[c]furanone system: ${ }^{5}$ Enyne ethers of type 5 formed bicyclic compounds $\mathbf{6}$ when the reaction was carried out in oxygen atmosphere while conversion in air gave monocyclic products 7 .

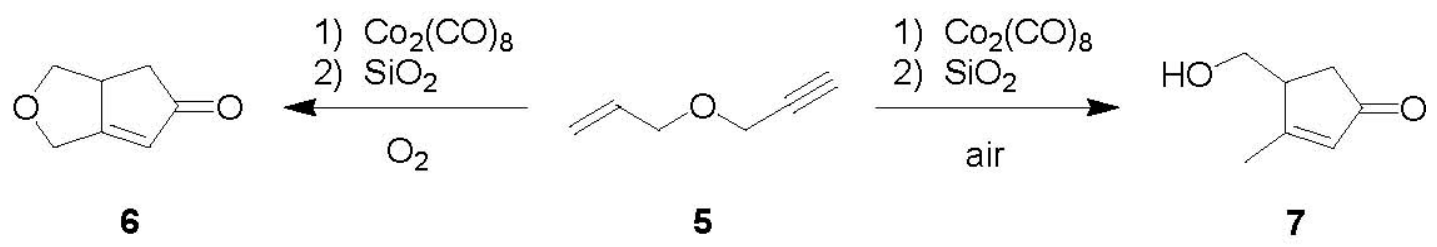

\section{Scheme 4}


Additional studies to further elucidate the profound influence of the atmosphere on the reaction pathway as well as the mechanism for the formation of perhydro nitrogen heterocycles of type 3 under DSAC are presently under way in this laboratory.

\section{Experimental Section}

General Procedures. Unless otherwise noted, chemicals were purchased from commercial suppliers and used without further purification. All solvents were distilled prior to use. Petroleum ether (PE) refers to the fraction of boiling range $40-60{ }^{\circ} \mathrm{C}$. Elemental analyses of novel compounds were carried out in the Microanalytical Laboratory, University of Vienna. The NMRspectra were recorded in $\mathrm{CDCl}_{3}$ solutions on a Bruker AC 200 (200 MHz) spectrometer, chemical shifts are reported in ppm using TMS as internal standard.

\section{One-pot DSAC Pauson-Khand cyclization of amides 1 and formation of ketones 3 . General procedure}

A $10 \%$ solution of precursor 1 ( 1 equiv.) in dry diethyl ether was added drop-wise to a stirred solution of $\mathrm{Co}_{2}(\mathrm{CO})_{8}$ (1 equiv.) in dry diethyl ether in a nitrogen atmosphere over a period of 20 min. Stirring was continued for $2 \mathrm{~h}$, then the brown complex 2 was diluted with dry diethyl ether and transferred to a baffled round bottom flask. To this solution silica gel (approx. $10 \mathrm{~g}$ per mmol of 1) was added, and the solvent was stripped off in vacuo on a rotary evaporator. After a nitrogen atmosphere had been established in the evaporator the water bath temperature was raised to $70{ }^{\circ} \mathrm{C}$ to induce cyclization, and the color of the reaction mixture slowly turned blue. The rotation of the flask was continued at this temperature for $3 \mathrm{~h}$, and subsequently, the product adsorbed on the silica gel was eluted on a chromatography column followed by purification via flash chromatography.

cis-2-Acetylperhydrocyclopenta[c]pyrrol-5-one (3a). Compound 3a was prepared according to the general procedure starting from $N$-allyl- $N$-(2-propynyl)acetamide (1a) (544 mg, $4.08 \mathrm{mmol}$ ). The cobalt residue was removed by flash chromatography $\left(\mathrm{MeOH} / \mathrm{PE} / \mathrm{CH}_{2} \mathrm{Cl}_{2}\right.$ 1:5:4). The crude product was purified by flash column chromatography (PE/EtOAc 1:1) to yield 3a $\mathbf{a}^{3,4 a}$ (410 mg, $60 \%$ ) as orange oil. ${ }^{1} \mathrm{H}$ NMR $\left(\mathrm{CDCl}_{3}\right): \delta 2.05(\mathrm{~s}, 3 \mathrm{H}), 2.18(\mathrm{dd}, J=6.5 \mathrm{~Hz}, J=20 \mathrm{~Hz}, 1 \mathrm{H}), 2.54$ $(\mathrm{dd}, J=6.5 \mathrm{~Hz}, J=20 \mathrm{~Hz}, 1 \mathrm{H}), 2.92-3.20(\mathrm{~m}, 2 \mathrm{H}), 3.30-3.46(\mathrm{~m}, 2 \mathrm{H}), 3.73-3.89(\mathrm{~m}, 2 \mathrm{H}) .{ }^{13} \mathrm{C}$ NMR $\left(\mathrm{CDCl}_{3}\right): \delta 22.1(\mathrm{q}), 37.7(\mathrm{~d}), 39.4(\mathrm{~d}), 41.8(\mathrm{t}), 41.9(\mathrm{t}), 50.0(\mathrm{t}) 51.7(\mathrm{t}), 169.1(\mathrm{~s}), 216.7$ (s).

cis-2-Trifluoroacetylperhydrocyclopenta[c]pyrrol-5-one (3b). Conversion according to the general procedure with $N$-allyl- $N$-(2-propynyl)trifluoroacetamide (1b) (760 mg, $3.98 \mathrm{mmol}$ ) followed by removal of the cobalt-residue via chromatography $\left(\mathrm{MeOH} / \mathrm{PE} / \mathrm{CH}_{2} \mathrm{Cl}_{2}\right.$ 1:5:4). Subsequent purification by flash chromatography (PE/EtOAc 1:1) gave $3 \mathbf{b}(400 \mathrm{mg}, 42 \%)$ as yellow oil. ${ }^{1} \mathrm{H}$ NMR $\left(\mathrm{CDCl}_{3}\right): \delta 1.94-2.30(\mathrm{~m}, 1 \mathrm{H}), 2.53(\mathrm{dd}, J=6.5 \mathrm{~Hz}, J=20 \mathrm{~Hz}, 1 \mathrm{H}), 2.86-$ $3.20(\mathrm{~m}, 2 \mathrm{H}), 3.41-3.61(\mathrm{~m}, 2 \mathrm{H}), 3.77-4.08(\mathrm{~m}, 2 \mathrm{H}) .{ }^{13} \mathrm{C} \mathrm{NMR}\left(\mathrm{CDCl}_{3}\right): \delta 36.9(\mathrm{~d}), 39.9(\mathrm{~d})$, 
$41.5(\mathrm{t}), 42.0(\mathrm{t}), 50.8(\mathrm{t}), 52.0(\mathrm{t}), 116.1\left(\mathrm{q}, J_{\mathrm{C}, \mathrm{F}}=288 \mathrm{~Hz}\right), 155.8\left(\mathrm{q}, J_{\mathrm{C}, \mathrm{F}}=37 \mathrm{~Hz}\right), 215.8(\mathrm{~s})$. Anal. calcd. for $\mathrm{C}_{9} \mathrm{H}_{10} \mathrm{NO}_{2} \mathrm{~F}_{3}$ (221.2): C, 48.87; H, 4.56; N 6.33. Found: C, 48.51; H, 4.33; N, 6.10 .

cis-2-Benzoylperhydrocyclopenta[c]pyrrol-5-one (3c). $N$-Allyl- $N$-(2-propynyl) benzamide (1c) $(1.08 \mathrm{~g}, 5.42 \mathrm{mmol})$ was reacted with $\mathrm{Co}_{2}(\mathrm{CO})_{8}$ as described above. The cobalt-residue was removed by chromatography $\left(\mathrm{MeOH} / \mathrm{PE} / \mathrm{CH}_{2} \mathrm{Cl}_{2}\right.$ 1:5:4), and the crude product was purified by flash chromatography (PE/EtOAc $1: 1)$ to give $3 \mathrm{c}^{3,4 \mathrm{a}}(0.95 \mathrm{~g}, 76 \%)$ as beige oil. ${ }^{1} \mathrm{H}$ NMR $\left(\mathrm{CDCl}_{3}\right): \delta 2.20(\mathrm{dd}, J=6.5 \mathrm{~Hz}, J=20 \mathrm{~Hz}, 1 \mathrm{H}), 2.43(\mathrm{dd}, J=6.5 \mathrm{~Hz}, J=20 \mathrm{~Hz}, 1 \mathrm{H}), 2.89(\mathrm{~m}$, 2H), $3.41(\mathrm{dd}, J=6.5 \mathrm{~Hz}, J=20 \mathrm{~Hz}, 2 \mathrm{H}), 3.80(\mathrm{dd}, J=6.5 \mathrm{~Hz}, J=20 \mathrm{~Hz}, 2 \mathrm{H}), 7.36(\mathrm{~m}, 5 \mathrm{H}) .{ }^{13} \mathrm{C}$ $\operatorname{NMR}\left(\mathrm{CDCl}_{3}\right): \delta 37.8(\mathrm{~d}), 39.8(\mathrm{~d}), 41.6(\mathrm{t}), 42.3(\mathrm{t}), 50.9(\mathrm{t}), 53.8(\mathrm{t}), 126.9(\mathrm{~d}), 128.2(\mathrm{~d}), 130.0$ (d), 136.3 (s), 169.9 (s), 216.9 (s).

cis-Methyl perhydro-5-oxocyclopenta[c]pyrrole-2-carboxylate (3d). Methyl $\mathrm{N}$-allyl- $\mathrm{N}$-(2propynyl)carbamate (1d) $(1.36 \mathrm{~g}, 8.88 \mathrm{mmol})$ was converted according to the above procedure. The cobalt residue was removed by flash chromatography ( $\mathrm{MeOH} / \mathrm{PE} / \mathrm{CH}_{2} \mathrm{Cl}_{2}$ 1:5:4). The crude product was purified by flash column chromatography (PE/EtOAc 1:1) to obtain 3d (1.00 g, $60 \%)$ as orange oil. ${ }^{1} \mathrm{H} \mathrm{NMR}\left(\mathrm{CDCl}_{3}\right): \delta 2.15(\mathrm{dd}, J=3.5 \mathrm{~Hz}, J=20 \mathrm{~Hz}, 1 \mathrm{H}) 2.52(\mathrm{dd}, J=3.5$ $\mathrm{Hz}, J=20 \mathrm{~Hz}, 1 \mathrm{H}), 2.84-3.05$ (m, 2H), 3.19-3.30 (m, 2H), 3.61-3.83 (m, 2H), 3.61-3.83 (s, 3H). ${ }^{13} \mathrm{C} \mathrm{NMR}\left(\mathrm{CDCl}_{3}\right): \delta 38.0(\mathrm{~d}), 38.9(\mathrm{~d}), 41.7(\mathrm{t}), 50.1(\mathrm{t}), 50.5(\mathrm{t}), 51.8(\mathrm{q}), 154.8(\mathrm{~s}), 216.9(\mathrm{~s})$. Anal. calcd. for $\mathrm{C}_{9} \mathrm{H}_{13} \mathrm{NO}_{3}$ (183.2): C, 59.00; H, 7.15; N 7.65. Found: C, 58.85; H, 6.99; N, 7.49. cis-1,1-Dimethylethyl perhydro-5-oxocyclopenta[c]pyrrole-2-carboxylate (3e). Conversion of tert-butyl $\mathrm{N}$-allyl- $\mathrm{N}$-(2-propynyl)carbamate (1e) $(1.20 \mathrm{~g}, 6.14 \mathrm{mmol})$ followed by separation of cobalt residues by chromatography $\left(\mathrm{MeOH} / \mathrm{PE} / \mathrm{CH}_{2} \mathrm{Cl}_{2} \quad 1: 5: 4\right)$ and purification via chromatography (PE/EtOAc 1:1) gave $3 \mathrm{e}^{4 \mathrm{~b}}(0.78 \mathrm{~g}, 56 \%)$ as pink crystals, mp: $69-70{ }^{\circ} \mathrm{C}$ (lit. $^{4}$ $\left.\operatorname{mp} 68-70.5^{\circ} \mathrm{C}\right)$.

cis-Perhydro-2-[(4-methylphenyl)sulfonyl)]cyclopenta[c]pyrrol-5-one (3f). Starting material $N$-allyl- $N$-(2-propynyl)-4-methyl-1-benzenesulfonamide (1f) $(500 \mathrm{mg}, 2.05 \mathrm{mmol})$ was treated as described above. Cobalt residues were removed by chromatography with methanol followed by purification via flash chromatography (PE/EtOAc 1:2) to obtain $3 \mathrm{f}^{4 \mathrm{a}}(290 \mathrm{mg}, 52 \%)$ as beige crystals, mp: $91-93{ }^{\circ} \mathrm{C} .{ }^{1} \mathrm{H}$ NMR $\left(\mathrm{CDCl}_{3}\right): \delta 2.01(\mathrm{dd}, J=6.5 \mathrm{~Hz}, J=20 \mathrm{~Hz}, 1 \mathrm{H}), 2.40(\mathrm{dd}, J=$ $6.5 \mathrm{~Hz}, J=20 \mathrm{~Hz}, 1 \mathrm{H}), 2.43(\mathrm{~s}, 3 \mathrm{H}), 2.80-2.95(\mathrm{~m}, 2 \mathrm{H}), 3.10(\mathrm{dd}, J=6.5 \mathrm{~Hz}, J=20 \mathrm{~Hz}, 1 \mathrm{H})$, $3.48(\mathrm{dd}, J=6.5 \mathrm{~Hz}, J=20 \mathrm{~Hz}, 1 \mathrm{H}), 7.36(\mathrm{~d}, J=9.4 \mathrm{~Hz}, 2 \mathrm{H}), 7.70(\mathrm{~d}, J=9.4 \mathrm{~Hz}, 2 \mathrm{H}) .{ }^{13} \mathrm{C} \mathrm{NMR}$ $\left(\mathrm{CDCl}_{3}\right): \delta 21.5(\mathrm{q}), 38.7(\mathrm{~d}), 42.3(\mathrm{t}), 53.2(\mathrm{t}), 127.5(\mathrm{~d}), 129.7(\mathrm{~d}), 132.8(\mathrm{~s}), 143.8(\mathrm{~s}), 216.9$ (s).

N-(2-Methyl-4-oxo-2-cyclopentenyl)methyltrifluoroacetamide (4). Product 4 was prepared according to the general procedure from $N$-allyl- $N$-(2-propynyl)trifluoroacetamide (1b) (500 mg, $2.38 \mathrm{mmol}$ ) in an oxygen atmosphere. Separation of the two compounds formed was performed by application of the chromatographic work-up as described for $\mathbf{3 b}$ to give beside the bicyclic product $3 \mathbf{b}(150 \mathrm{mg}, 30 \%)$ also 4 (30 mg, 5\%) as a colorless oil. ${ }^{1} \mathrm{H}$ NMR $\left(\mathrm{CDCl}_{3}\right): \delta 2.10-2.29$ $(\mathrm{m}, 4 \mathrm{H}), 2.61(\mathrm{dd}, J=5 \mathrm{~Hz}, J=19.5 \mathrm{~Hz}, 1 \mathrm{H}), 3.02-3.22(\mathrm{~m}, 1 \mathrm{H}), 3.47-4.08(\mathrm{~m}, 2 \mathrm{H}), 6.02$ (s, 1H), $7.18\left(\right.$ broad s, 1H). ${ }^{13} \mathrm{C} \mathrm{NMR}\left(\mathrm{CDCl}_{3}\right): \delta 17.5(\mathrm{q}), 40.0(\mathrm{t}), 41.2(\mathrm{t}), 43.9(\mathrm{~d}), 116.0\left(\mathrm{q}, J_{\mathrm{C}, \mathrm{F}}=\right.$ 
287Hz), 132.8 (d) 155.4 (q, $J_{\mathrm{C}, \mathrm{F}}=37 \mathrm{~Hz}$ ), 176.5 (s), 216.3 (s). Anal. calcd. for $\mathrm{C}_{9} \mathrm{H}_{10} \mathrm{NO}_{2} \mathrm{~F}_{3}$ (221.2): C, 48.87; H, 4.56; N 6.33. Found: C, 48.60; H, 4.39; N, 6.26.

\section{Acknowledgements}

Funding by the Oesterreichische Nationalbank (grant no. JF-7619) is gratefully acknowledged. We would like to thank Baxter Immuno Austria for supporting the project.

\section{References}

1. For comprehensive reviews see: (a) Schore, N.E. Chem. Rev. 1988, 88, 1081. (b) Schore, N. E. Comprehensive Organic Synthesis 1991, Vol.5, p. 1037. (c) Fletcher, A. J.; Christie, S. D. R. J. Chem. Soc Perkin Trans. I 2000, 1657.

2. (a) Chen, G.; Kayser, M. M.; Mihovilovic, M. D.; Mrstik, M. E.; Martinez, C. A.; Stewart, J. D. New J. Chem. 1999, 8, 827. (b) Mihovilovic, M. D.; Müller, B.; Kayser, M. M.; Stewart, J. D.; Fröhlich, J.; Stanetty, P.; Spreitzer, H. J. Mol. Catal. B: Enzym. 2001, 11, 349.

3. Pauson, P.L.; Brown, S.W. J. Chem. Soc., Perkin Trans 1 1990, 1205.

4. (a) Becker, D. P.; Flynn, D. L. Tetrahedron Lett. 1993, 34, 2087. (b) Becker, D. P.; Daniel, P. Tetrahedron 1993, 49, 5047.

5. (a) Smit, W. A.; Simonyan, S. O.; Tarasov, V. A.; Mikaelyan, G. S.; Gybin, A. S.; Ibragimov, I. I.; Caple, R.; Froen, D.; Kreager, A. Synthesis 1989, 472. (b) Smit, A; Simonyan, S. O. Tetrahedron Lett. 1986, 27, 1245.

6. Belanger, D. B.; O’Mahony, D. J. R.; Livinghouse, T. Tetrahedron Lett. 1998, 39, 7637.

7. (a) Vilenchik, Y. M.; Grunina, V. P.; Perova, N. M.; Zayakina, L. P. Khim. Prom-st., Ser.: Reakt. Osobo Chist. Veshchestva 1979, 1; Chem. Abstr. 1980, 93, 94744. (b) Boger, D. L.; Tarby, C. M.; Myers, P. C. J. Am. Chem. Soc. 1996, 118, 2109. 